\title{
KEMAMPUAN INTELEKTUAL, KEDISIPLINAN, MOTIVASI, DAN PENGAWASAN TERHADAP PROFESIONALISME GURU SEKOLAH MENENGAH KEJURUAN DI KOTA SURAKARTA
}

\author{
Rini Udayanti, Istiatin, Bambang Mursito \\ Program Pascasarjana Universitas Islam Batik Surakarta \\ Email:mfriniuda@gmail,com
}

\begin{abstract}
The research purpose was determined the effect of intellectual ability, discipline, supervision, and motivation on the vocational high school teachers' professionalism in the Surakarta City. The research type is explanatory research. The research population are teachers of Vocational High School in Surakarta City. Sampling technique was used purposive sampling technique. Technique of data collection was used questionnaires. Data analysis techniques were used statistical analysis including of multiple linear tests, F-test, and t-test. The research results showed that 1) intellectual ability, discipline, supervision, and work motivation are simultaneously have a significant effect on the vocational high school teachers' professionalism in Surakarta City. 2) Intellectual abilities has significant effect on the vocational high school teachers' professionalism in Surakarta City. 3) Discipline has a significant effect on vocational high school teachers' professionalism in the Surakarta city. 4) Work motivation has significant effect on the vocational high school teachers' professionalism in Surakarta City. 5) Supervision has significant effect on the vocational high school teachers' professionalism in Surakarta.
\end{abstract}

Keywords: intellectual ability, discipline, supervision, work motivation, professionalism

\section{PENDAHULUAN}

Guru adalah pekerjaan profesional yang menuntut guru untuk menunjukkan sikap profesional. Guru harus bangga mendapatkan sebutan profesional. Guru yang profesional dituntut untuk dengan konsekuensi tinggi, memiliki semangat yang kuat untuk mendidik anak, mengembangkan kemampuan seiring dengan kemajuan teknologi (Nurhayati, 2017).

Usaha memajukan sikap profesional guru harus selalu dilakukan terus menerus dan tidak berhenti pada satu titik kesuksesan saja. Cara meningkatkan sikap profesional adalah meningkatkan standar profesional guru. Guru harus berani dan mau bekerja keras untuk melakukan perbaikan dalam sikap mengajar dan kualias profesionalisme guru. Standar profesional guru berjenjang mulai dari kabupaten, propinsi dan pusat yang mana standar tersebut harus mengacu pada standar nasional pendidikan. Peningkatan profesionalisme guru bertujuan supaya pendidikan Indonesia bisa dibandingkan dengan negara lain di tingkat internasional (Riswandi, 2016).

Pengembangan profesionalisme guru perlu dilaksanakan secara terus menerus mengingat guru merupakan kunci sukses implementasi kurikulum yang saat ini dilaksanakan. Oleh karena itu, guru dituntut mengembangkan sikap profesionalnya dengan menetapkan standard mutu personal yang meliputi kewibawaan, tanggung jawab pada pekerjaan, kedisiplinan tinggi, dan mandiri dalam melaksanakan tugas kewajibannya. Guru merupakan pemeran utama kegiatan pembelajaran yang berinteraksi langsung dengan peserta didik dalam proses kegiatan proses belajar mengajar. Berhasil tidaknya upaya peningkatan kualitas pendidikan banyak ditentukan oleh kemampuan yang ada pada guru dalam mengemban tugas pokok sebagai pengelola kegiatan 
pembelajaran di kelas. Pentingnya peranan guru mengharuskan guru untuk memiliki kompetensi yang sesua dengan tuntutan profesi (Riswandi, 2016).

Upaya pembentukan guru profesional diperlukani pengetahuan-pengetahuan tentang pendidikan, psikologi, kurikulum, metode mengajar, dasar danitujuan pendidikan moral, nilainilai dan norma-norma, yang kesemuanya itu dapat diperoleh melalui pendidikan guru. Profesionalisme guru diharapkan dapat meningkatkani belajar siswa, baik yang menyangkut pengetahuan, keterampilan, kemampuan, maupun sikap hidup. Hasil belajar siswa banyak ditentukan oleh faktor kemahiran guru dalam mengajar di kelas. Di samping ipropesionalitas guru dalam menentukan hasil belajar juga sikap disiplin guru. Disiplin muncul karena adanya keinginan untuk menyeimbangkan antara sesuatu yang dilaksanakan orang dengan yang diinginkan dan dilaksanakan orang lain yang sesuai terhadap batas dan peraturan tertentu serta memenuhi harapan orang lain sesuai dengan kemampuannya (Amin, 2016).

Guru dengan sikap profesional tinggi tampak dari sikap perilaku dan kemauan untuk mewujudkan dan meningkatkan kualitas keprofesionalan mereka dengan bermacam cara dan metode untuk memperbaiki mutu pendidikan kepada siswa. Diduga faktor yang mempengaruhi sikap profesional guru adalah kemampuan intelektual, kedisiplinan, motivasi, dan pengawasan.

Sikap profesional diwujudkan oleh seseorang dengan meningkatkan sikap profesional dan secara berkelanjutan mengembangkan strategi untuk melaksanakan tugas yang menjadi tanggung jawabnya. Guru yang bersikap profesional dalam menjalankan tugas mengajar dengan meningkatkan kemampuan mengajar dan menunjukkan sikap yang menunjukkan kualitas mengajar sesuai dengan tuntutan profesional; dan selalu mensandarkan perilakunya pada tatanan profesionalisme (Kunandar, 2010: 25).

Guru diharuskan selalu menunjukkan kemampuan intelektual yang tinggi karena sistem pendidikan menuntut guru untuk selalu memperbarui pengetahuannya agar bisa mengajar sesuai dengan tuntutan kurikulum. Tingkat kemampuan intelektual yang tinggi maka tingkat profesionalisme otomatis akan meningkat. Tingkat profesional seorang pegawai ditentukan keterampilan dan kecerdasan seorang guru (Soegeng, 2017)

Peningkatan kualitas kinerja dan profesionalisme guru dapat ditingkatkan melalui pelaksanaan disiplin guru yang tinggi. Karyawan dengan disiplin yang kuat meningkatkan kemungkinan suatu lembaga terebut untuk mencapai tujuan yang ditetapkan. Pencapaian tujuan tersebut tidak bisa dipisahkan dari kepatuhan terhadpa aturan yang ditetapkan, ketaatan pada sistem kerja, dan melaksanakan pekerjaan dengan tanggung jawab. Untuk meningkatkan kedisiplinan lembaga pendidikan dapat melakukan pengawasan terhadap guru supaya menjalankan kewajibannya secara bertanggung jawab (Sepang, 2018).

Sabania (2018) menyatakan bahwa guru yang bergelar profesional harus mempunyai semangat kerja (motivasi) yang tinggi sehingga akan mendorong guru tersbut untuk selalu menaikkan keterampilan dalam membuat perencanaan pembelajaran, menerapkan dalam pembelajaran, melakukan evaluasi terhadap pembelajaran yang dilaksanakan sehingga kinerja guru bisa optimal. Motivasi yang diberikan secara benar dapat mengubah sikap pegawai untuk selalu mendapatkan kinerja yang maksimal. Kemampuan profesionalsme guru perlu ditingkatkan dengan memberikan motivasi yang sesuaikan dengan keinginan lembaga pendidikan, sehingga pada akhirnya profesionalisme guru akan meningkat.

Wahjuni (2017) berpendapat bahwa supervisi kepada guru sangat dibutuhkan guna membimbing guru supaya pekerjaan yang diamatkan kepada mereka bisa dilaksanakan secara tepat dan tidak menyimpang dari peraturan yang ada. Supervisi atau pengawasan merupakan sarana yang utama dalam membina kemampuan bawahan, karena pengawasan adalah salah satu motivator bagi pegawai untuk berperilaku sesuai dengan peraturan yang berlaku di organisasi tersebut. Pengawasan dipergunakan pimpinan untuk imengetahui tugas nyata yang dilakukan 
oleh karyawan serta mengetahui permasalahan pelaksanaan tugas yang dihadapi dalam lingkungan organisasi dan jika terjadi penyimpangan, dapat dengan mudah mengambil langkah perbaikan dan tindakan sesuai dengan rencana yang telah ditetapkan sebelumnya.

Hal tersebut sejalan dengan hasil banyak penelitian yang menunjukkan bahwa faktor pengawasan tersebut berpengaruh terhadap profesionalisme guru. Dharmawan (2013) menyatakan bahwa peningkatan sikap profesional dapat mempengaruhi peningkatan kinerja pegawai. Hal yang mempengaruhi peningkatan sikap profesional antara lain kemampuan intelektual, emosional, dan spiritual pegawai tersebut.

Tripsilanti (2019) menyatakan bahwa disiplin memiliki efek yang signifikan pada sikap profesional para guru. Motivasi memiliki efek signifikan pada sikap profesionalisme guru. Sementara itu Sabania (2018) menyatakan bahwa motivasi kerja berhubungan dengan sikap profesional guru.

Kartini (2014) menyebutkan bahwa kedisiplinan memiliki pengaruh pada sikap profesional guru yang berarti disiplin guru yang tinggi, maka profesional guru juga meningkat, demikian juga sebaliknya. Motivasi guru juga berpengaruh terhadap sikap profesional guru yang berarti bahwa motivasi yang tinggi maka sikap profesional guru juga semakin meningkat.

Penelitian di atas menunjukkan belum adanya penelitian mengenai kemampuan intelektual, kedisiplinan, pengawasan, dan motivasi terhadap profesionalisme guru. Sehingga penelitian ini dilaksanakan untuk menganalisis pengaruh antar variabel kemampuan intelektual, kedisiplinan, pengawasan, dan motivasi terhadap profesionalisme guru SMK di Kota Surakarta.

Penelitian ini memiliki tujuan menganalisis ada tidaknya pengaruh kemampuan intelektual, kedisiplinan, pengawasan, dan motivasi secara parsial dan simultan pada profesionalisme guru SMK Kota Surakarta.

\section{METODE PENELITIAN}

Penelitian ini adalah penelitin explanatory research. Explanatory research adalah jenis penelitian bertujuan menganalisis hubungan sebab akibat variabel yang diaplikasikan di dalam penelitian dengan menguji hipotesa yang diajukan (Sugiyono, 2016: 35). Sementara itu, peneliti ini menerapkan pendekatan kuantitatif. Pendekatan kuantitatif merupakan suatu jenis penelitian yang mana proses pengumpulan, analisis, dan interpertasi data dilaksanakan menurut analisis data dalam bentuk angka.

Populasi penelitian adalah guru SMK Kota Surakarta. Sampel penelitian berjumlah 47 guru yang berasal dari SMK Santo Paulus Surakarta (20 guru) dan SMK Muhammadiah 4 Suakarta (27 guru). Cara mengambil sampel dari populasi dilakukan dengan menerapkan purposive sampling technique. Data primer dan sekunder digunakan dalam penelitian ini. Data penelitian dikumpulkan menggunakan teknik pengamatan, kuesioner (angket), studi dokumen, dan kajian pustaka.

Instrumen penelitian diuji menggunakan validitas dan reliabilitas. Validitas intrumen penelitian diuji menggunakan teknik korelasi "Product Moment". Reliabilitas angket ditentukan menggunakan rumus Alpha Cronbach. Apabila $r_{\text {Alpha }}$ Cronbach $>0,60$, yang berarti kuesioner tersebut reliabel. Hasil analisis pengujian instrumen penelitian tambah bahwa instrumen yang digunakan adalah valid dan reliabel.

Prasyarat analisis dalam penelitian ini menggunakan uji normalitas, heterokedastisitas, multikolineritas, dan autokorelasi. Uji hipotesis dilakukan dengan koefisien determinasi, uji regresi, uji ketepatan model (F-test), dan uji parameter penduga (t-test) 


\section{HASIL DAN PEMBAHASAN}

\section{Koefisien Determinasi $\left(\mathbf{R}^{\mathbf{2}}\right)$}

Koefisien determinasi digunakan untuk mengukur besarnya pengaruh varibel bebas kemampuan intelektual (X1), kedisiplinan (X2), Motivasi (X3) dan Pengawasan (X4), terhadap variabel terikat Profesionalisme Guru (Y). Hasil analisis koefisien determinasi (R2) dapat dilihat pada tabel sebagai iberikut:

Tabel 1. Analisis Koefisien Determinasi $\left(\mathrm{R}^{2}\right)$

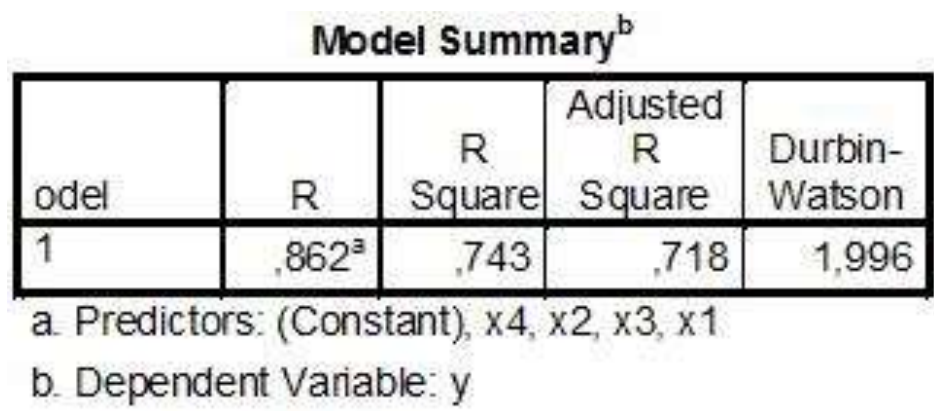

Hasil analisis nilai $\mathrm{R}^{2}$ diperoleh $0,743(74,3 \%)$. Hasil tersebut dapat disimpulkan bahwa kemampuani variabeli independen kemampuan intelektual (X1), kedisiplinan (X2), Motivasi (X3) dan Pengawasan (X4) untuk menentukan Profesionalisme (Yi) adalah sebesari 74,3\%, selebihnya sebanyak $25,7 \%$ dijelaskani oleh faktori lain yang tidak dijelaskani dalami model regresi.

\section{Analisis Regresi Linier Berganda}

Pengujian analisis regresi berganda dimaksudkan untuk menentukan pengaruh variabel kemampuan intelektual (X1), kedisiplinan (X2), Motivasi (X3) dan Pengawasan (X4) terhadap Profsionalime Guru (Y).

Tabel 2 Analisis Regresii Berganda

\begin{tabular}{|c|c|c|c|}
\hline \multirow[b]{2}{*}{ Model } & $\begin{array}{l}\text { Unstandardized } \\
\text { Coefficients } \\
\end{array}$ & & \\
\hline & B & $\mathrm{T}$ & Sig. \\
\hline $1 \quad$ (Constant) & $-14,330$ & $-2,187$ &, 034 \\
\hline$x 1$ & 330 & 2,039 & 048 \\
\hline$x 2$ &, 562 & 3,362 &, 002 \\
\hline$\times 3$ & 1,008 & 4,141 &, 000 \\
\hline$x 4$ & 1,054 & 4,258 & 000 \\
\hline
\end{tabular}

Analisis regresi linier berganda di atas, dapat dirumuskan suatu persamaan regresi linier berganda sebagai berikut: $\mathrm{Y}=-14,330+0,330 \mathrm{X} 1+0,562 \mathrm{X}_{2}+1,008 \mathrm{X}_{3}+1,054 \mathrm{X}_{4}+\mathrm{e}$

Nilai konstanta $=-14,330$. Hal ini iberarti bahwa, apabila nilai kemampuan intelektual (X1), kedisiplinan (X2), Motivasi (X3) dan Pengawasan (X4) konstan, maka besarnya variabel dependen Profesionalism Guru (Y) adalah sebesar -14,330 satu satuan.

Nilai koefisien b1 $=0,330$, berarti bahwa bila nilai variabel kemampuan intelektual (X1) imengalami kenaikan sebesar satu satuan, sedangkan variabel independen kedisiplinan (X2), 
motivasi (X3) dan pengawasan (X4) tetap, maka Profesionalisme Guru (Y) akan meningkat 0,330 satuan.

Nilai koefisien b2 $=0,562$, berarti bahwa bila nilai variabel kedisiplinan (X2) mengalami kenaikan sebesar satu satuan, sedangkan variabel independen kemampuan intelektual (X1), motivasi (X3) dan pengawasan (X4) tetap, maka Profesionalisme Guru (Y) akan meningkati 0,562 satuan.

Nilai koefisien b3 $=1,008$, berarti bahwa bila nilai variabel motivasi (X3) mengalami kenaikan sebesar satu satuan, sedangkan variabel independen kemampuan intelektual (X1), kedisiplinan (X2) dan pengawasan (X4) tetapi, maka Profesionalisme Guru (Y) akan meningkati 1,008 satuan.

Nilai koefisien b4 $=1,054$, berarti bahwa bila nilai variabel pengawasan $(\mathrm{X} 4)$ mengalami kenaikan sebesar satu satuan, sedangkan variabel independen kemampuan intelektual (X1), kedisiplinan (X2), dan motivasi (X3) tetapi, maka Profesionalisme Guru (Y) akan meningkat sebesar 1,054 satuan.

\section{Uji F}

Uji F ibertujuan iuntuk imengetas kesesuaian model yang dirumuskan dalam penelitian. Uji F (Anova) menyatakan apakah variabel independen penelitian (kemampuan intelektual, kedisiplinan, motivasi, dan pengawasan) berkontribusi secara bersama terhadap variabel dependen (profesionalisme guru).

Uji $\mathrm{F}$ digunakan untuk melihat signifikansi pengaruh dar variabel kemampuan intelektual (X1), kedisiplinan (X2), Motivasi (X3) dan Pengawasan (X4) secara bersamai-sama terhadap variabel terikat Profesionalisme Guru (Y) dengan level of significant $\alpha=5 \%$. Analisa tersebut dapat diketahui dengan membandingkani nilai $F_{\text {hitung }}$ dengan nilai $F_{\text {tabel }}$ dan bisa juga dengan melihat nilai signifikansinya.

Tabel 3 Uji Koefisien Regresi Berganda

\begin{tabular}{|c|c|c|c|c|c|}
\hline Model & \begin{tabular}{|l|} 
Sum of \\
Squares \\
\end{tabular} & df & $\begin{array}{c}\text { Mean } \\
\text { Square } \\
\end{array}$ & $\mathrm{F}$ & Sig. \\
\hline \multirow{2}{*}{$\begin{array}{ll}1 & \text { Regression } \\
& \text { Residual }\end{array}$} & 1518,599 & 4 & \multirow{3}{*}{$\begin{array}{r}379,650 \\
12,802\end{array}$} & \multirow[t]{3}{*}{$\overline{29,656}$} & \multirow[t]{3}{*}{$000^{6}$} \\
\hline & 524,879 & 41 & & & \\
\hline Total & 2043,478 & 45 & & & \\
\hline
\end{tabular}

Analisis regresi berganda pada tabel di atas menunjukkan bahwa $F_{\text {hitung }}$ sebesar 29,656 dan $F_{\text {tabel }}$ sebesar 2,60 sehingga dapat dikatakan bahwa $F_{\text {hitung }}>F_{\text {tabel }}$ sehingga Ha diterima yang bermakna bahwa secara simultan (bersama-sama) variabel kemampuan intelektual (X1), kedisiplinan (X2), Motivasi (X3) dan Pengawasan (X4) memiliki pengaruh terhadap profesionalisme guru (Y)

\section{Uji t}

Uji-t dilaksanakan untuk menguji pengaruh parsial (individual) variabel bebas (kemampuan intelektual, kedisiplinan, motivasi, dan pengawasan) terhadap variabel terikat (profesionalisme guru) pada taraf kepercayaan $\alpha=5 \%$. Syarat penarikan kesimpulan penelitian adalah:

1) Jika $t_{\text {hitung }} \geq t_{\text {tabel }}$ bermakna bahwa Ho ditolak dan Ha diterima, artinya variabel bebas berpengaruh signifikan terhadap variabel terikat. 
2) Jika $t_{\text {hitung }} \leq t_{\text {tabel }}$ bermakna bahwa Ho diterima sedangkan Ha ditolak, hal ini berarti bahwa variabel bebas tidak memiliki pengaruh signifikan terhadap variabel terikat.

Tabel 4. Hasil Uji-t

\begin{tabular}{|c|c|c|c|c|c|}
\hline \multirow[b]{2}{*}{ Model } & \multicolumn{2}{|c|}{$\begin{array}{l}\text { Unstandardized } \\
\text { Coeffic ients }\end{array}$} & \multirow{2}{*}{$\begin{array}{c}\text { Standardized } \\
\text { Coefficients } \\
\text { Beta } \\
\end{array}$} & \multirow[b]{2}{*}{$\mathrm{t}$} & \multirow[b]{2}{*}{ Sig. } \\
\hline & $\mathrm{B}$ & $\begin{array}{l}\text { Std. } \\
\text { Error }\end{array}$ & & & \\
\hline 1 (Constant) & $-14,330$ & 6,552 & & $-2,187$ &, 034 \\
\hline $\mathrm{x} 1$ &, 330 &, 162 & ,193 & 2,039 &, 048 \\
\hline$x 2$ &, 562 & , 167 & ,281 & 3,362 &, 002 \\
\hline x3 & 1,008 & 243 &, 383 & 4,141 &, 000 \\
\hline $\mathrm{x} 4$ & 1,054 & 247 &, 375 & 4,258 &, 000 \\
\hline
\end{tabular}

Pada variabel kemampuan intelektual $\left(\mathrm{X}_{1}\right) \mathrm{t}_{\text {hitung }}>\mathrm{t}_{\text {tabel }}(2,039>1.68288)$, hal ini memiliki arti Ha diterima. Sehingga dapat dikatakan bahwa kemampuan intelektual (X1) berpengaruh signifikan pada profesionalisme guru (Y). Kondisi ini menunjukkan kemampuan intelektual memiliki pengaruh signifikan pada profesionalisme guru. Hal ini bermakna bahwa jika kemampuan intelektual tinggi maka profesionalisme juga akan meningkat.

Variabel kedisiplinan guru $(X 2) t_{\text {hitung }}>t_{\text {tabel }}(3,362>1,68288)$, hal ini memiliki arti Ha diterima. Sehingga dapat dikatakan bahwa kedisiplinan (X2) berpengaruh signifikan pada profesionalisme guru (Y). Kondisi ini menunjukkan kemampuan intelektual memiliki pengaruhi signifikan pada profesionalisme guru. Hal ini bermakna bahwa jika kedisiplinan tinggi maka profesionalisme juga akan meningkat.

Variabel motivasi kerja $(\mathrm{X} 3) \mathrm{t}_{\text {hitung }}>\mathrm{t}_{\text {tabel }}(4,141>1,68288)$, hal ini memiliki arti Ha diterima. Sehingga dapat dikatakan bahwa motivasi (X3) berpengaruh signifikan pada profesionalisme guru (Y). Artinya motivasi memiliki pengaruh signifikan pada profesionalisme guru, sehingga bila motivasi tinggi imakai iprofesionalisme gurui juga akan meningkat.

Variabel pengawasan $(X 3) t_{\text {hitung }}>t_{\text {tabel }}(4,258>1,68288)$, hal ini memiliki arti Ha diterima. Sehingga dapat dikatakan bahwa pengawasan (X3) berpengaruh signifikan pada profesionalisme guru (Y). Artinya pengawasan memiliki pengaruh signifikan pada profesionalisme guru, sehingga bila pengawasan tingg maka profesionalisme guru juga akan meningkat.

\section{PEMBAHASAN}

Pengaruh kemampuan intelektual, kedisiplinan, pengawasan, dan motivasi kerja secara simultan terhadap profesionalisme guru SMK Kota Surakarta

Hasil uji $\mathrm{F}$ secara simultan dinyatakan bahwa kemampuan intelektual, kedisiplinan, motivasi, dan pengawasan menunjukkan pengaruh signifikan pada profesionalisme guru. Artinya adanya perubahan peningkatan kemampuan intelektual, kedisiplinan, motivasi, dan pengawasan bersama-sama mempengaruhi sikap profesional seorang guru. Naik turunnya kemampuan intelektual, kedisiplinan, motivasi, dan pengawasan berdampak positif pada meningkatnya sikap profesional guru.

Hasil penelitian ini selaras dengan penelitian Tripsilanti (2019) menyimpulkan bahwa kedisiplinan memiliki dampak positif terhadap sikap profesional guru dan motivasi memiliki dampa popsitif terhadap sikap profesional guru. Sabania (2018) menyebutkan bahwa motivasi berhubungan terhadap sikap profesional guru. Penelitian Nurhayati (2017) juga menyatakan bahwa variabel motivasi bersama variabel lainya secara bersama-sama berpengaruh terhadap profesionalisme guru. 
Tanda yang menunjukkan guru profesional adalah guru memiliki pemahaman terhadap materi, konsep, dan struktur materi mata pelajaran yang ditugaskan kepadanya. Selain itu guru profesional harus imemahami ikompetensi intii idan ikompetensi idasar imata ipelajaran yang menjadi tugasnya, scara aktif dan kreatif mengembangkan pelajaran, dan mampu memberdayakan teknologi informasi untuk meningkatkan kemampuan intelektualnya.

Penelitian ini menunjukkan bahwa kemampuan intelektual, kedisiplinan, motivasi, dan pengawasan secara bersama-sama (simultan) berpengaruh signifikan pada profesionalisme guru. Hasil ini dapat terwujud karena guru mempunyai motivasi kerja yang tinggi sehingga bersemangat untuk bekerja profesional, selain itu guru juga mempunyai kemampuan bekerja dan keseriusan dalam menjalankan tugas-tugasnya. Sikap profesional guru juga ditunjukkan dengan guru menunjukkan jiwa pengabdian (dedikasi) yang tinggi dalam melaksanakan tugasnya. Sikap profesional guru adalah faktor yang menentukan mutu pendidikan nasional, sehingga perlu upaya nyata untuk meningkatkan mutu guru. Sikap profesional guru juga tampak dari sikap guru dalam menjalankan tugas dan kewajibannya yang menunjukkan sikap kerja yang berguna untuk mempertajam kualitas pendidikan.

\section{Pengaruh kemampuan intelektual terhadap profesionalisme guru SMK Kota Surakarta}

Hasil penelitian ini menunjukkan bahwa kemampuan intelektual memilikii pengaruh positif dan nyata pada sikap profesionalisme guru. Hal ini bermakna bahwa jika kemampuan intelektual guru ditingkatkan, maka secara otomatif profesionalisme guru juga akan meningkat. Kondisi ini tampak pada perilaku guru ketika melaksanakan tugas mendidik siswa di kelas. Sehingga dapat dikatakan bahwa kemampuan intelektual harus selalu ditingkatkan supaya guru sebagai individu yang profesional mampu memperoleh kesuksesan dalam berkarir profesional sebagai pendidik (ya Al Said, dkk, 2013).

Penelitian ini juga semakin memberikan gambaran nyata bahwa kemampuan intelektual berdampak signifikan terhadap sikap profesional guru. Guru profesional membutuhkan kemampuan intelektual tinggi untuk mencapai kesukesan dalam karirnya. Guru profesional selalu mendasarkan tindakannya dalam bekerja berdasarkan ilmu pengetahuan yang mereka miliki. Arti kehidupan bagi guru presional adalah membangun dan meningkatkan kemajuan serta kecerdasan bangsa (Agustian, 2012: 35)

Kemampuan intelektuan seseorang merupakan ciri individu yang membedakan dengan individu lainnya. Kecerdasan intelektual digunakan untuk memecahakan masalah logika maupun strategi. Kecerdasan intelektual adalah daya reaksi atau penyesuaian yang secara tepat, baik secara fisik maupun mental terhadap pengalaman baru atau membuat pengalaman dan pengetahuan yang telah dimiliki siap untuk digunakan ketika berhadapan dengan situasi dan kenyataan baru.

Tingkat profesionalisme guru tampak dari tinggi rendahnya kemampuan intelektual seorang guru. Kemampuan intelektual merupakan keterampilan dasar yang dimiliki guru yang dimanfaatkan dalam pemecahan masalah yang dihadapinya. Sehinigga dapat dikatakan bawa, dengan kemampuan intelektual menentukan cara guru untuk berpikir rasional dan kemampuan guru untuk bertindak dalam menghadapi lingkungan masyarakat. Kemampuan intelektual seorang guru menunjukkani kecerdasan yang dimiliki oleh seorang guru.

\section{Pengaruh kedisiplinan terhadap profesionalisme guru SMK Kota Surakarta}

Hasil penelitian ini menunjukkan bahwa kedisiplinan guru memiliki pengaruh signifikan pada sikap profesional guru. Hal ini berarti bahwa apabila kedisiplinan guru ditingkatkan maka sikap profesional guru juga meningkat. Hasil penelitian ini sejalan dengan Kartini (2014) yang menyimpulkan bahwa disiplin berdampak pada profesionalisme guru. Sementara itu, Tripsilanti 
(2019) menyatakan bahwa sikap disiplin memiliki pengaruh ipositif dan signifikan iterhadap profesionalisme guru.

Disiplin muncul karena adanya keinginan untuk menyeimbangkan antara sesuatu yang dilaksanakan orang dengan yang diinginkan dan dilaksanakan orang lain yang sesuai terhadap batas dan peraturan tertentu serta memenuhi harapan orang lain sesuai dengan kemampuannya (Amin, 2016). Sikap disiplin diterapkan agar pegawai atau karyawan mentaati standard dan peraturan sehingga dapat mencegah kemungkinan terjadinya pelanggaran.

Siswanto (dalam Kartini, 2014) Menyatakan bahwa seorang yang memiliki disiplin tinggi dapat dilihat dari berbagai indikator antara lain tingkat kehadiran di tempat kerja, kewaspadaan, kesanggupan memenuhi standar kerja, kepatuan pada aturan kerja, dan menjunjung tinggi etika kerja. Tujuan penerapan disiplin ini adalah menciptakan kondisi kerja yang sehat dan timbulkan sikap saling menghormati di antara pegawai. Seorang guru harus memiliki standar disiplin tinggi dalam melaksanakan tugas dan kewajibannya, karena disiplin merupakan salah satu penentu profesionalisme guru.

Tingkat kedisiplinan guru ditujukkan oleh sikap kepatuhan guru terhadap peraturan yang berhubungan dengan tugas dan kewajiban sebagai pengajar dalam proses pembelajaran di sekolah. Sehingga indikator kedisiplinan guru dapat dilihat dari kehadiran guru di kelas, proses belajar mengajar, dan program follow up yang dikembangkan guru dalam menjalankan tugasnya sebagai pengajar di sekolah.

\section{Pengaruh motivasi terhadap sikap profesional guru SMK Kota Surakarta}

Hasili analisis penelitian ini menunjukkan adanya pengaruh signifikan motivasi pada profesionalisme guru. Ini bermakna bahwa peningkatan imotivasi guru akan meningkatkan profesionalisme guru. Hasil penelitian ini didukungi oleh penelitian Tripsilanti (2019) yang menyatakan bahwa motivasi memilik pengaruh signifikan pada profesionalisme. Sementara itu, Kartini, G.Ngarifah Rindang Ilmi (2014) imenyatakan bahwa motivasi kerja memiliki dampak positif yang signifikan pada profesionalisme guru. Sabania (2018) menyatakan bahwa motivasi kerja berhubungan signifikan dengan sikap profesional guru.

Guru dengan motivasi kerja tinggi akan bekerja dengan semangat yang tinggi untuk memajukan lembaga pendidikan yang menaunginya. Motivasi kerja guru bermanfaat untuk meningkatkan upaya guru dalam meraih prestasi terbaik. Motivasi kerja yang berasal dari dalam diri guru memberikan kesadaran mengenai pentingnya tanggung jawab terhadap tugas yang diembannya yang lebih baik dibandingkan motivasi dari luar guru. Guru yang memiliki motivasi kerja tinggi akan melaksanakan pembelajaran yang menyenangkan bagi siswa sehingga berdampak pada pencapai prestasi dan kinerja optimal dari seorang guru.

\section{Pengaruh pengawasan terhadap profesionalisme guru SMK Kota Surakarta}

Hasil analisis data dalam penelitian ini menunjukkan bahwa pengawasan memiliki dampak signifikan pada profesionalisme guru. Hal ini bermakna bahwa tingkat pengawasan yang tinggi akan meningkatkan profesionalisme guru. Hasil penelitian ini sejalan dengan penelitiani Muhajirin; Prihatin, Titi; Yusuf, Amin (2017) yang menyatakan bahwa pengawasan (supervisi akademik) berpengaruh terhadap profesionalisme guru.

Pengawasan terhadap pegawai adalah unrut penting dalam pelaksanaan pembinaan pegawai di suatu perusahaan, karena pengawasan adalah faktor pendorong bagi pegawai atau bawahan untuk berperilaku sesuai peraturan yang ditetapkan di perusahaan. Pengawasan adalah salah satu tugas dari pimpinan dalam rangka pembinaan dan pencegahan terhadap kemungkinan terjadinya pelanggaran disiplin pegawai. Dengan adanya pengawasan yang tepat sasaran, pimpinan perusahaan dapat mengetahui pelaksanaan tugas karyawan (pegawai) dan kemungkinan 
permasalahan yang dihadapi serta cara untuk memecahkannya serta memperbaiki kemungkinan penyimpangan yang terjadi (Meika, et al., 2017).

Pengawasan atau supervisi adalah salah satu fungai manajemen yang paling penting. Tanpa adanya pengawasan yang baik pekerjaan tidak dapat dilaksanakan dengan baik. Upaya meningkatkan pengawasan untuk mendisiplinkan pegawai dapat dilaksanakan dengan beberapa cara yaitu menetapkan standar kerja yang meliputi standar perencanaan, pelaksanaan, dan evaluasi pegawai dalam peride waktu tertentu. Evaluasi dilaksanakan untuk membandingkan hasil yang dicapai dengan standar yang telah ditetapkan sebelumnya. Pengawasan juga dapat mendeteksi penyelewangan pegawai terhadap standar dan ukuran yang telah ditentukan, sehingga dapat segera dilaksanakan perbaikan atas penyelewengan tersebut.

\section{KESIMPULAN}

Berdasarkan hasil penelitian tentang pengaruhi kemampuan intelektual, kedisiplinan, pengawasan, dan motivasi terhadap profesionalisme guru Sekolah Menengah Kejuruan di Kota Surakarta, maka dapat idisimpulkan ibahwa:

1) Kemampuan intelektual, kedisiplinan, pengawasan, dan motivasi kerja secara simultan (bersama-sama) berpengaruh signifikan terhadap profesionalisme guru SMK Kota Surakarta.

2) Kemampuan intelektual berpengaruh signifikan terhadap profesionalisme guru SMK Kota Surakarta

3) Kedisiplinan berpengaruh signifikan terhadap profesionalisme guru SMK Kota Surakarta

4) Motivasi kerja berpengaruh signifikan terhadap profesionalisme guru SMK Kota Surakarta.

5) Pengawasan berpengaruh signifikan terhadap profesionalisme guru SMK Kota Surakarta.

6) Nilai koefisien determinasi $\left(\mathrm{R}^{2}\right)$ sebesar $0,743 \quad(74,3 \%)$ yang berarti bahwa bahwa kemampuan variabel independen kemampuan intelektual, kedisiplinan, Motivasi dan pengawasan untuk menentukan profesionalisme adalah sebesar 74,3\%, selebihnya sebanyak $25,7 \%$ dijelaskan oleh variabel lain yang tidak dimasukkan dalam penelitian ini.

7) Persamaan regresi linier berganda hasil analisis regresi dirumuskan $Y=-14,330$ $0,330 \mathrm{X} 1+0,562 \mathrm{X}_{2}+1,008 \mathrm{X}_{3}+1,054 \mathrm{X}_{4}+\mathrm{e}$

\section{DAFTAR PUSTAKA}

Agustian, Ary Ginanjar. 2012. Emotional spiritual quotient (the esq way 165). PT Arga Tilanta. Jakarta

Al Said, Tagharid Bint Turki; dkk. 2013. Phycometry propertis ofbar-on emotionall quoetient inventori youth version among omani children. International Journal of Management Systems. United Kingdom. No.02, 13-24

Amin, Mohammad Taufiqurrachman. 2016. Pengaruh Professionalitas dan Kedisiplinan Guru Terhadap Prestasi Kinerja Guru Sma Negeri 1 Pademawu Kabupaten Pamekasan. Jurnal Penelitian dan Pendidikan IPS (JPPI) Volume 10 No 1 (2016) 119-131 ISSN (Print) : 18584985.

Kartini, G.Ngarifah Rindang Ilmi. 2014. "Kontribusi Disiplin, Motivasi Kerja dan Sarana Prasarana terhadap Profesionalisme Guru SMK N I Ngawi. Naskah Publikasi. Universitas Muhammadiyah Surakarta.

Kunandar. 2010. Guru Profesional. Jakarta: PT Raja Grafindo Persada 
Meika, Intan; Pramono, Rudy Eko; dan Wahjuni, Sri. 2017. Pengaruh Pengawasan terhadap Disiplin Kerja Karyawan pada Koperasi Margo Mulyo Ambulu, Kabupaten Jember. ESOSPOL Vol. IV Edisi 1 Jan - Apr 2017 hal. 56- 61

Muhajirin; Prihatin, Titi; Yusuf, Amin. 2017. Pengaruh Supervisi Akademik dan Partisipasi Guru pada MGMP Melalui Motivasi Kerja Terhadap Profesionalisme Guru SMA/MA. $\begin{array}{lllllllll}\text { Educational } & \text { Management. } & \text { EM } & 6 & \text { (2) } & \text { (2017) } & 170 & \text { - } & 177 .\end{array}$ http://journal.unnes.ac.id/sju/index.php/eduman

Nurhayati. 2017. School Leadership, Personality, dan Motivasi, terhadap Profesionalisme Guru Sekolah Dasar. Jurnal Pendidikan Dasar Volume 6 Edisi 1 mei 2017.

Nurhayati. 2017. School Leadership, Personality, dan Motivasi, terhadap Profesionalisme Guru Sekolah Dasar. Jurnal Pendidikan Dasar Volume 6 Edisi 1 mei 2017.

Riswandi. 2016. Pengaruh Budaya Organisasi, Komitmen Dan Motivasi Berprestasi Terhadap Profesionalisme Guru. Jurnal FKIP Unila.

Sabania, Siti. 2018. Hubungan Motivasi Kerja dengan Profesionalisme Guru SD Se-kecamatan Wawotobi Kabupaten Konawe. Jurnal Al-Ta'dib Vol. 11 No.2, Juli - Desember.

Sepang, Jantje L, Rumimpunu, Reinhard J; Lengkong, Victor P. K;. 2018. Pengaruh Profesionalisme, Kompetensi dan Disiplin Kerja terhadap Kinerja Pegawai Di Badan Perencanaan Pembangunan Daerah (Bappeda) Provinsi Sulut. Jurnal EMBA. Vol.6 No.4 September 2018, Hal. 3358 - 3367

Soegeng, AY, Ulfah, Choiriyah; Yuliejantiningsih, dan Yovitha. 2017. Pengaruh Kompensasi Dan Motivasi Kerja Terhadap Profesionalisme Guru Paud Di Kecamatan Ungaran Barat Kabupaten Semarang. Jurnal Universitas PGRI Semarang.

Sugiyono. 2016. Metode Penelitian Kombinasi (Mixed Method). Bandung: Penerbit Alfabeta

Tripsilanti, Umi. 2019. Kedisiplinan, Kreatifitas, dan Motivasi Berprestasi Guru terhadap Profesionalisme Guru MAN Di Kabupaten Kebumen. Journal of Educational Evaluation Studies (JEES), 1 (1), 2019 Available online at: http://jurnal.ustjogja.ac.id/index.php/JEES

Wahyuning, Tri; Ambarita, Alben; dan Riswandi. 2016. Pengaruh Budaya Organisasi, Komitmen Dan Motivasi Berprestasi Terhadap Profesionalisme Guru. Jurnal FKIP Unila 